\title{
ISOLATION AND STRUCTURAL ELUCIDATION OF A NEW DEPSIDE OF LICHEN Everniopsis trulla
}

\author{
Olivio Nino Castro Mandujano ${ }^{1, *}$, Jesús López Rodilla², Sofia Pombal², \\ Francisca Sanz González ${ }^{3}$, Julio Santiago Contreras ${ }^{1}$
}

\begin{abstract}
In this research, a new depside of the lichen Everniopsis trulla has been isolated. The extraction was carried out to $400 \mathrm{~g}$ of dry sample and ground with ethanol for 3 repetitions, then, it was fractionated by applying column chromatography with the $\mathrm{CHCl}_{3}-\mathrm{MeOH}$ system and purified by recrystallization with $\mathrm{MeOH}-A c e t o n e ~(1: 1)$; Finally, white crystals in the form of needles (solid C) with a melting point of $198^{\circ} \mathrm{C}$ were obtained, whose structure was elucidated based on spectroscopic data (UV-Visible, IR, NMR-H1, NMR-C ${ }^{13}$, mass spectrometry and single crystal X-ray diffraction). According to the Science Finder databases, it is a new depside, called trullarin, and it is observed that molecular packing is influenced by both intramolecular and intermolecular forces. Intermolecular hydrogen bonds of $\mathrm{O}-\mathrm{H} \cdots \mathrm{O}$ type binds neighboring molecules forming dimers.
\end{abstract}

Key words: Crystal structure; Depside; Everniopsis trulla; Trullarin

\section{AISLAMIENTO Y ELUCIDACIÓN ESTRUCTURAL DE UN NUEVO DÉPSIDO DEL LIQUEN Everniopsis trulla}

\footnotetext{
RESUMEN

En esta investigación se ha aislado a un nuevo dépsido del liquen Everniopsis trulla. Se realizó la extracción a $400 \mathrm{~g}$ de muestra seca y molida con etanol por 3 repeticiones, luego, se fraccionó aplicando cromatografía en columna con el sistema $\mathrm{CHCl}_{3}-\mathrm{MeOH}$ y purificó por recristalización con $\mathrm{MeOH}$-Acetona (1:1); finalmente se obtuvo unos cristales blancos en forma de agujas (sólido C) de punto de fusión de $198^{\circ} \mathrm{C}$, el cual se elucidó su estructura en base a los datos espectroscópicos (UV-Visible, IR, RMN-H $\mathrm{H}^{1}, \mathrm{RMN}-\mathrm{C}^{13}$, espectrometría de masas y difracción de monocristales de rayos X). Según la base de datos de Science

${ }^{1}$ Facultad de Química e Ing. Química, Universidad Nacional Mayor de San Marcos, Calle Germán Amézaga 375, Lima 1, Perú. Email O. Castro: ocastro@unmsm.edu.pe; J. Santiago: jsantiagoc@unmsm.edu.pe.

2 Departamento de Química, Unidade FibEnTech, Universidade da Beira Interior, 6201-001 Covilhã, Portugal. Email J. Rodilla: rodilla@ubi.pt; S. Pombal: sofia.pombal@gmail.com.

${ }^{3}$ Servicio de Difracción de Rayos X, Universidad de Salamanca, Facultad de Ciencias, Plaza de la Merced s/n; E-37008 Salamanca, España. Email: sdrayosx@usal.es.
} 
Finder, se trata de un nuevo dépsido, llamado trullarin y se observa que el empaquetamiento molecular está influenciado por fuerzas tanto intramoleculares como intermoleculares. Enlaces de hidrógeno intermoleculares del tipo $\mathrm{O}-\mathrm{H} \cdots \mathrm{O}$ enlaza las moléculas vecinas formando dímeros.

Palabras clave: Estructura cristalina; dépsido; Everniopsis trulla; trullarin.

\section{INTRODUCTION}

Biomass has become in recent years an alternative source of molecular scaffolds for the synthesis of the next generation of bioactive compounds (nutraceuticals, antioxidants, antimicrobials, insecticides, drugs or materials). The presence of one or more chiral atoms in these metabolites increases their utility in the development of new drugs. Moreover, biomass processing often generates by-products useful in other industries1. A well-known example is the generation of 5-hydroxymethylfurfural (HMF) from the dehydration of fructose. The HMF can be transformed into different furan derivatives, such as 2,5-bis (hydroxymethyl) furan, which is an optimal substrate for the manufacturing of polyurethane foam with better flame hazards properties ${ }^{2}$.

Lichens are organisms widespread in nature, and are of particular interest in medicinal chemistry due to the wide variety of metabolites associated to their biomass. The use of xanthones has been reported for the synthesis of new molecules with better antifungal properties. Likewise, usnic acid, a major metabolite identified in many lichens, has been used to generate several derivatives with antimicrobial and tuberculostatic properties ${ }^{3,4}$.

Depsides are polyphenolic compounds comprising two or more monocyclic aromatic units, linked by an ester bond. They are often found in lichens, but have also been isolated from plants from the Ericaceae, Lamiaceae, and Papaveraceae family. Depsides have antibiotic, anti-HIV, and antiproliferative activities. As inhibitors of prostaglandin biosynthesis and leukotriene B4 biosynthesis, depsides are considered potent nonsteroidal anti-inflammatory compounds 5 .

The Parmeliaceae is a large and diverse family of Lecanoromycetes. A botanical study of all genera of Parmeliaceae family includes information on basic morphological characteristics for each species, but up to date there is no specific information regarding their phytochemical and pharmacological characteristics ${ }^{6}$. Previous research performed on the lichen Everniopsis trulla (Ach.) Nyl, (family Parmeliaceae), identified atranorin and usnic acid contained in the thallus surface. Tri-terpenes and $\beta$-orcinol depsidones were also found in its medulla ${ }^{6}$. In another study, the compounds chloratranorin and atranorin were identified from two extracts of $E$. trulla by TLC. The presence of two additional unknown substances was also detected ${ }^{7}$.

In this paper, the chemical structure of a new depside isolated from lichen E. trulla (Ach.) $N y l$ is presented, which increases the knowledge about the metabolites present in this species. 


\section{EXPERIMENTAL PART}

Sample. The lichen specimen Everniopsis trulla (400 g) was collected in "Canchas city", Asunción (Huaraz, Peru), in 2011 at an altitude of 3427 meters (10,650 feet). A voucher specimen was deposited in the Museum of Natural History of National University of San Marcos, UNMSM, Lima, Peru.

\section{Extraction and isolation}

The powdered sample generated from E. trulla, was extracted successively with ethanol The chloroform extract was run through a chromatographic column (silica gel, $\mathrm{CHCl} 3$ $\mathrm{MeOH}$ gradient) isolating five compounds: solid A (usnic acid), solid B (atranorin), solid C (trullarin), 2,4-dihydroxy-3-formyl-6-methylbenzoate (ethyl haematommate) and a compound still unidentified). Trullarin was purified by crystallization. Colourless single crystals were obtained by crystallization from EtOH/H2O (mp: 198-199 ${ }^{\circ} \mathrm{C}$ ).

\section{RESULTS AND DISCUSSION}

Usnic acid, atranorin and 2,4-dihydroxy-3-formyl-6-methylbenzoate were identified by comparison of their spectroscopic data with the literature ${ }^{9,13,14}$.

\section{Trullarin chemical structure elucidation}

Trullarin was identified as depside through qualitative chemical reactions. This compound reacted with $\mathrm{NaOCl}$ and $\mathrm{Ca}(\mathrm{OCl})_{2}$ in solution to give red and orange colors; It also reacted with p-phenylenediamine to give red and orange colors. This reactivity is typical of a depside with an aromatic aldehyde moiety ${ }^{8,9}$. The chemical structure of trullarin was elucidated using ${ }^{1} \mathrm{H}-\mathrm{NMR},{ }^{13} \mathrm{C}-\mathrm{NMR}$, UV and IR spectroscopies. The confirmation of the structure of trullarin was accomplished by single-crystal X-ray diffraction analysis.

${ }^{1} \mathrm{H}-\mathrm{NMR}$ (benzene-d6, 400MHz): $\delta$ (ppm) 12.70, 12.65, 12.44 (each 1H, s, Ar-OH), 10.24 $(1 \mathrm{H}, \mathrm{s},-\mathrm{CHO}), 6.28$ (1H, s, Ar-H), 3.25 (3H, s, - CO2Me), 2.33, 2.11 (each 3H, s, Ar-Me 5 and 6), 2.23 and 2.25 (each 3H, s, Ar-Me 3' and 5'). See figure 1. 


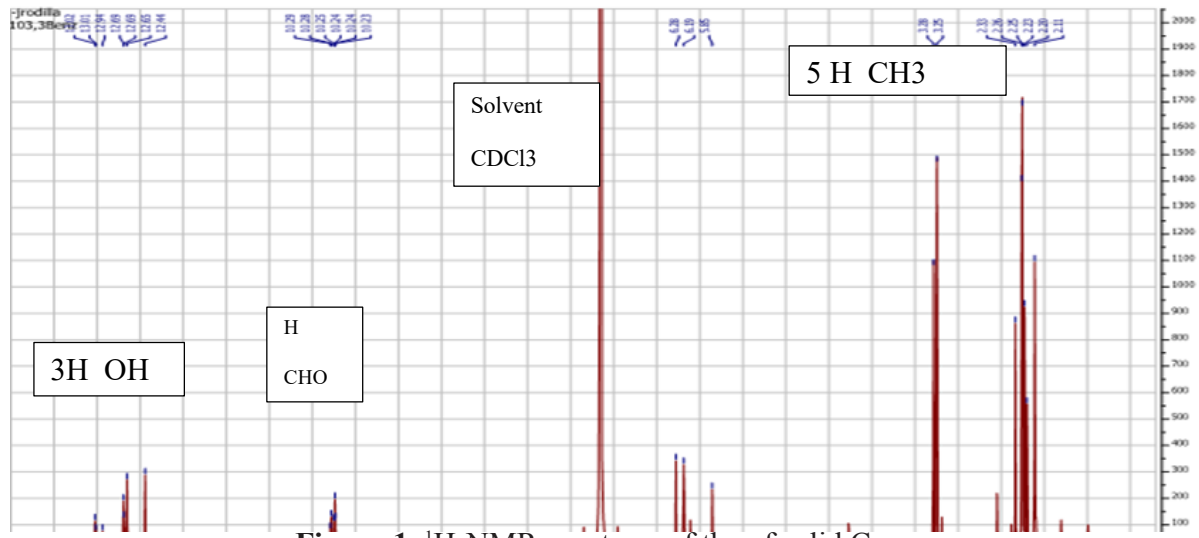

Figura 1. ${ }^{1} \mathrm{H}-\mathrm{NMR}$ spectrum of the of solid' $\mathrm{C}$.

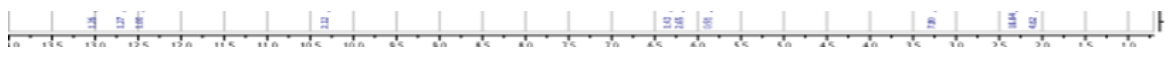

Figure 1. ${ }^{1} \mathrm{H}-\mathrm{NMR}$ spectrum of the of solid $\mathrm{C}$

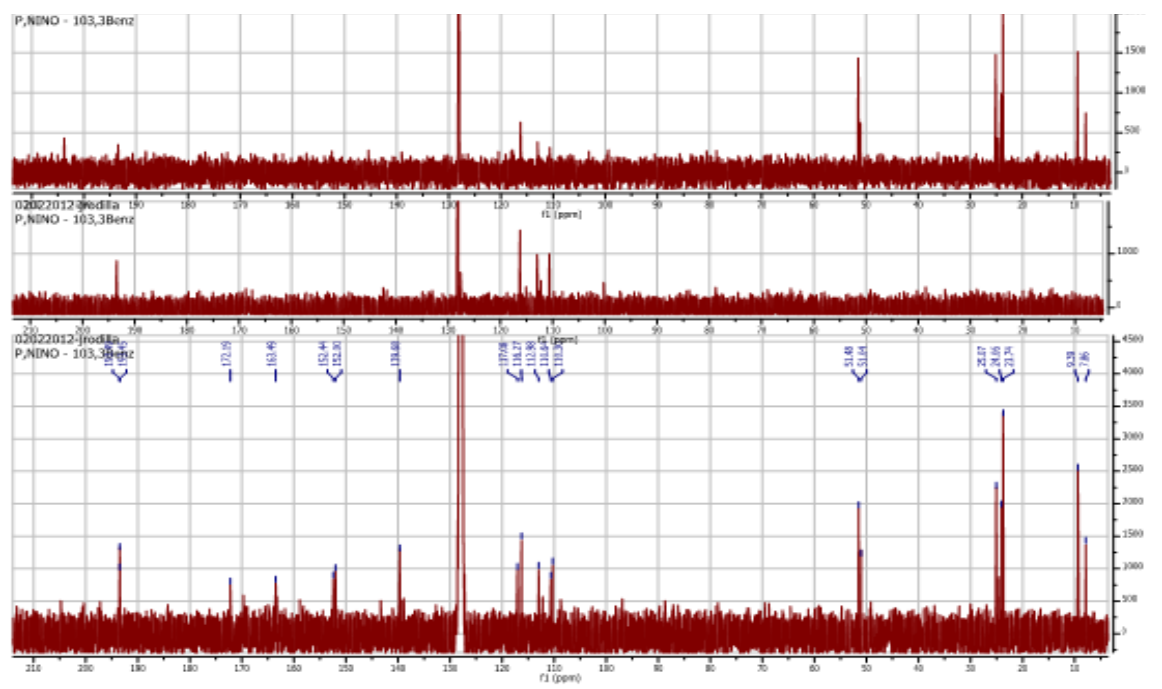

Figura 2. ${ }^{13} \mathrm{C}-\mathrm{NMR}$ spectrum and DEPT the of solid C. 
${ }^{13} \mathrm{C}-\mathrm{NMR}$ (benzene-d6, 100MHz): showed five methyl groups at $\delta 9.4,23.7,24.0,25.1$ in two aromatic rings and 51.4 for the methyl ester. It also showed two carbonyl esters at $\delta 163.5$ and 172.2 and showed an aldehyde group at $\delta 193.4 \mathrm{ppm}$ in C-3. See figure 2.

MS: HRMS m/z 389.1624 (calcd for C20H21O8, 389.1622).

UV: $\lambda \max$ in ethanol $219.3 \mathrm{~nm}$ and $269.5 \mathrm{~nm}$.

IR (KBr, cm $\left.{ }^{-1}\right): 3090,3002,1651,1622,1582,1451,1407,1268,1163,1106,820,802,610$.

This compound called trullarin is new according to the PUCP BASE OF SCIENCE FINDER. Its chemical name is: (Methyl-2,6-dimethyl-4 '- (3-formyl-2,4-dihydroxy-5,6imethylbenzoyloxy) -3'-hydroxy benzoate). HRESIMS (negative mode): m / z 387.1071 [M$\mathrm{H}]+$ (calculated for $\mathrm{C} 20 \mathrm{H} 19 \mathrm{O} 8$ : 387.1080). The title compound named trullarin, $\mathrm{C}_{20} \mathrm{H}_{20} \mathrm{O}_{8}$, crystallizes with one molecule in the asymmetric unit in the monoclinic centrosymmetric space group $\mathrm{P} 2 \mathrm{l} / \mathrm{n}$ with the following unit cell parameters: $\mathrm{a}=11.0400(3) \AA, \mathrm{b}=11.2752(3)$ $\AA, c=14.7893(4) \AA, \alpha=\gamma=90^{\circ}, \beta=109.074(2)^{\circ}, V=1739.87(8) \AA 3, Z=4$. Figure 3 shows the molecular structure in solid state, in which the individual conformation of trullarin can be observed. The crystallographic data is presented in Table 1. Selected bond lengths and angles are given in Table 2. All the bond lengths and angles are within the normal ranges.

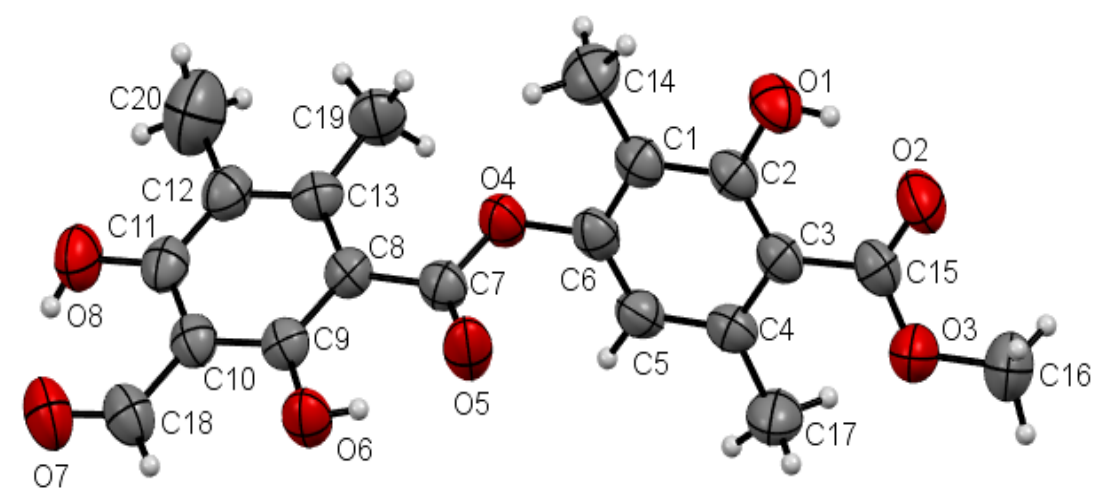

Figura 3. Molecular structure of trullarin. 
Tabla 1. Crystallographic data for $\mathrm{C}_{20} \mathrm{H}_{20} \mathrm{O}_{8}$.

\begin{tabular}{|c|c|}
\hline $\mathrm{CCDC}$ & 1508526 \\
\hline Empirical formula & $\mathrm{C}_{20} \mathrm{H}_{20} \mathrm{O}_{8}$ \\
\hline Formula weight & 388.36 \\
\hline Temperature (K) & $298(2)$ \\
\hline Wavelength $(\AA)$ & 1.54178 \\
\hline Crystal system & Monoclinic \\
\hline Space group & $\mathrm{P} 2{ }_{1} / \mathrm{n}$ \\
\hline Unit cell dimensions & \\
\hline $\mathrm{a}(\AA)$ & $11.0400(3)$ \\
\hline $\mathrm{b}(\AA)$ & $11.2752(3)$ \\
\hline c $(\AA)$ & $14.7893(4)$ \\
\hline$\alpha\left[^{\circ}\right], \beta\left[^{\circ}\right], \gamma\left[^{\circ}\right]$ & $90,109.074(2), 90$ \\
\hline Volume $\left(\AA^{3}\right), \mathrm{Z}$ & $1739.87(8), 4$ \\
\hline Density (calculated $\left(\mathrm{Mgm}^{-3}\right)$ & 1.483 \\
\hline Absorption coefficient $\left(\mathrm{mm}^{-1}\right)$ & 0.975 \\
\hline $\mathrm{F}(000)$ & 816 \\
\hline Crystal size (mm) & $0.15 \times 0.10 \times 0.08$ \\
\hline Range for data collection $\theta\left(^{\circ}\right)$ & 4.38 to 66.90 \\
\hline Limiting indices $\mathrm{h}, \mathrm{k}, \mathrm{l}$ & $-13 \leq \mathrm{h} \leq 13,-12 \leq \mathrm{k} \leq 13,-17 \leq 1 \leq 14$ \\
\hline Reflections collected & 11153 \\
\hline Independent reflections & $2934\left(\mathrm{R}_{\text {(int) }}=0.0312\right)$ \\
\hline Refinement method & Full-matrix least-squares on $\mathrm{F}^{2}$ \\
\hline Data / restraints / parameters & 2934 / 0 / 262 \\
\hline Goodness-of-fit on $\mathrm{F}^{2}$ & 1.065 \\
\hline Final $R$ indices $[I>2 \sigma(I)]$ & $\mathrm{R}_{1}=0.0678, \mathrm{wR}_{2}=0.2309$ \\
\hline $\mathrm{R}$ indices (all data) & $\mathrm{R}_{1}=0.0819, \mathrm{wR}_{2}=0.2556$ \\
\hline Largest diff. peak and hole & 0.270 y -0.765 \\
\hline
\end{tabular}


Tabla 2. Selected bond lengths $(\AA)$ and bond angles $\left({ }^{\circ}\right)$ for $\mathrm{C}_{20} \mathrm{H}_{20} \mathrm{O}_{8}$.

\begin{tabular}{|l|l|l|l|}
\hline Bond & Length (A) & Diedral angles & Angles () \\
$\mathrm{O}(1)-\mathrm{C}(2)$ & $1.353(3)$ & $\mathrm{C}(15)-\mathrm{O}(3)-\mathrm{C}(16)$ & $117.3(3)$ \\
$\mathrm{O}(2)-\mathrm{C}(15)$ & $1.227(4)$ & $\mathrm{C}(7)-\mathrm{O}(4)-\mathrm{C}(6)$ & $117.8(2)$ \\
$\mathrm{O}(3)-\mathrm{C}(15)$ & $1.308(4)$ & $\mathrm{O}(1)-\mathrm{C}(2)-\mathrm{C}(3)$ & $122.6(3)$ \\
$\mathrm{O}(3)-\mathrm{C}(16)$ & $1.449(4)$ & $\mathrm{C}(1)-\mathrm{C}(6)-\mathrm{O}(4)-\mathrm{C}(1)$ & $115.0(2)$ \\
$\mathrm{O}(4)-\mathrm{C}(7)$ & $1.345(3)$ & $\mathrm{C}(5)-\mathrm{C}(6)-\mathrm{O}(4)$ & $117.4(3)$ \\
$\mathrm{O}(4)-\mathrm{C}(6)$ & $1.414(3)$ & $\mathrm{O}(5)-\mathrm{C}(7)-\mathrm{O}(4)$ & $120.7(3)$ \\
$\mathrm{O}(5)-\mathrm{C}(7)$ & $\mathrm{O}(5)-\mathrm{C}(7)-\mathrm{C}(8)$ & $124.3(2)$ \\
$\mathrm{O}(6)-\mathrm{C}(9)$ & $1.212(3)$ & $\mathrm{O}(4)-\mathrm{C}(7)-\mathrm{C}(8)$ & $115.0(2)$ \\
$\mathrm{O}(7)-\mathrm{C}(18)$ & $1.328(3)$ & $\mathrm{O}(6)-\mathrm{C}(9)-\mathrm{C}(10)$ & $115.3(2)$ \\
$\mathrm{O}(8)-\mathrm{C}(11)$ & $1.227(4)$ & $\mathrm{O}(6)-\mathrm{C}(9)-\mathrm{C}(8)$ & $123.5(3)$ \\
$\mathrm{C}(7)-\mathrm{C}(8)$ & $1.336(3)$ & $\mathrm{O}(8)-\mathrm{C}(11)-\mathrm{C}(12)$ & $118.9(3)$ \\
& $1.468(4)$ & $\mathrm{O}(8)-\mathrm{C}(11)-\mathrm{C}(10)$ & $120.8(3)$ \\
& & $\mathrm{O}(2)-\mathrm{C}(15)-\mathrm{O}(3)$ & $121.7(3)$ \\
& & $\mathrm{O}(2)-\mathrm{C}(15)-\mathrm{C}(3)$ & $122.7(3)$ \\
& & $\mathrm{O}(3)-\mathrm{C}(15)-\mathrm{C}(3)$ & $115.6(2)$ \\
& & $\mathrm{O}(7)-\mathrm{C}(18)-\mathrm{C}(10)$ & $123.4(3)$ \\
\hline
\end{tabular}

The planar conformation of the ester groups is established from the torsion angles O3-C15$\mathrm{O} 2-\mathrm{C} 3=-178.5(5)$ and $\mathrm{O} 4-\mathrm{C} 7-\mathrm{O} 5-\mathrm{C} 8=179.3(5)$. The hydroxyl groups are coplanar with the aromatic rings; the $\mathrm{O} 1-\mathrm{C} 2-\mathrm{C} 1-\mathrm{C} 6, \mathrm{O} 6-\mathrm{C} 9-\mathrm{C} 10-\mathrm{C} 11$ and $\mathrm{O} 8-\mathrm{C} 11-\mathrm{C} 12-\mathrm{C} 13$ torsion angles are $-179.9(3)^{\circ}, 179.5(3)^{\circ}$ and $-179.6(3)^{\circ}$, respectively.

In the crystal structure of trullarin, there are two benzene rings in the molecule. $\mathrm{C}(1), \mathrm{C}(2)$, $\mathrm{C}(3), \mathrm{C}(4), \mathrm{C}(5)$ and $\mathrm{C}(6)$ form the first plane, with a mean deviation of $0.0167 \AA$, defined as plane I. Similarly, C(8), C(9), C(10), C(11), C(12) and C(13) forms the second plane with a mean deviation of $0.0048 \AA$, defined as plane II. The dihedral angle between plane I and plane II is $64.4(9)^{\circ}$. In addition, the ester group $\mathrm{C}(7), \mathrm{C}(8), \mathrm{O}(4)$ and $\mathrm{O}(5)$ forms a third plane, defined as plane III. The dihedral angle between plane II and plane III is $4.3(1)^{\circ}$, which suggests that both are nearly co-planar. This indicates that there is a $\pi-\pi$ conjugation between the $\mathrm{C}(=\mathrm{O})$ group and the benzene ring of plane $\mathrm{II}^{15,16}$.

The molecular packing of trullarin is influenced by both intramolecular and intermolecular forces. Intramolecular forces determine molecular shape, which in turn play an important 
role in determining the most effective ways of packing the molecules in the crystal [13]. In the structure, there are three intramolecular hydrogen bonds of $\mathrm{O}-\mathrm{H} \cdots \mathrm{O}$ type. The $\mathrm{O} 1 \cdots \mathrm{O} 2$, $\mathrm{O} 5 \cdots \mathrm{O} 6$ and $\mathrm{O} 7 \cdots \mathrm{O} 8$ intramolecular hydrogen bonds generate a six-membered rings (Table 3 and Fig. 4). Furthermore, one intermolecular hydrogen bond of $\mathrm{O}-\mathrm{H} \cdots \mathrm{O}$ type, O5 $\cdots \mathrm{O} 6$, links adjacent molecules into dimers (Table 3 and Fig. 4). The dimers form twelve-membered rings and present an anti-parallel orientation along an axis. The packing diagram in Fig. 5 shows the stacking pattern of trullarin, viewed along the [010] direction. The chemical structure obtained by single crystal XRD agrees very well with NMR spectroscopy data.

Tabla 3. Intra- and Intermolecular hydrogen bonds geometry $\left(\AA,{ }^{\circ}\right)$ for $\mathrm{C}_{20} \mathrm{H}_{20} \mathrm{O}_{8}$.

\begin{tabular}{|c|c|c|c|c|}
\hline $\mathbf{D}-\mathbf{H} \cdots \mathbf{A}$ & $\mathbf{D}-\mathbf{H}$ & $\mathbf{H} \cdots \mathbf{A}$ & $\mathbf{D} \cdots \mathbf{A}$ & $\mathbf{D}-\mathbf{H} \cdots \mathbf{A}$ \\
$\mathrm{O} 1-\mathrm{H} 1 \cdots 2^{\mathrm{i}}$ & 0.82 & 1.81 & $2.540(3)$ & 147 \\
$\mathrm{O} 6-\mathrm{H} 6 \cdots \mathrm{O}^{\mathrm{i}}$ & 0.82 & 1.83 & $2.541(3)$ & 144 \\
$\mathrm{O} 8-\mathrm{H} 8 \cdots \mathrm{O}^{\mathrm{i}}$ & 0.82 & 1.83 & $2.554(4)$ & 146 \\
$\mathrm{O} 6-\mathrm{H} 6 \cdots{ }^{\mathrm{ii}}$ & 0.82 & 2.52 & $3.088(3)$ & 127 \\
\hline
\end{tabular}

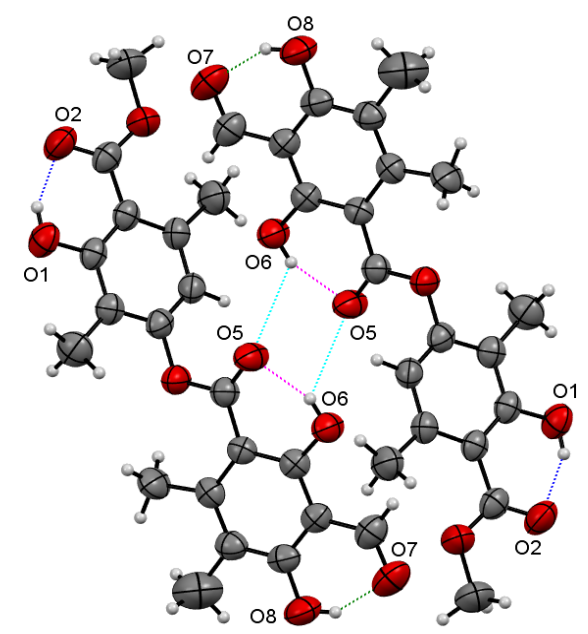

Figura 4. Intermolecular hydrogen bonding in trullarin.

The chemical structure obtained by single crystal XRD aligns very well with NMR spectroscopy data. Figure 6, shows the chemical structure of the isolated new compound from E. trulla. 


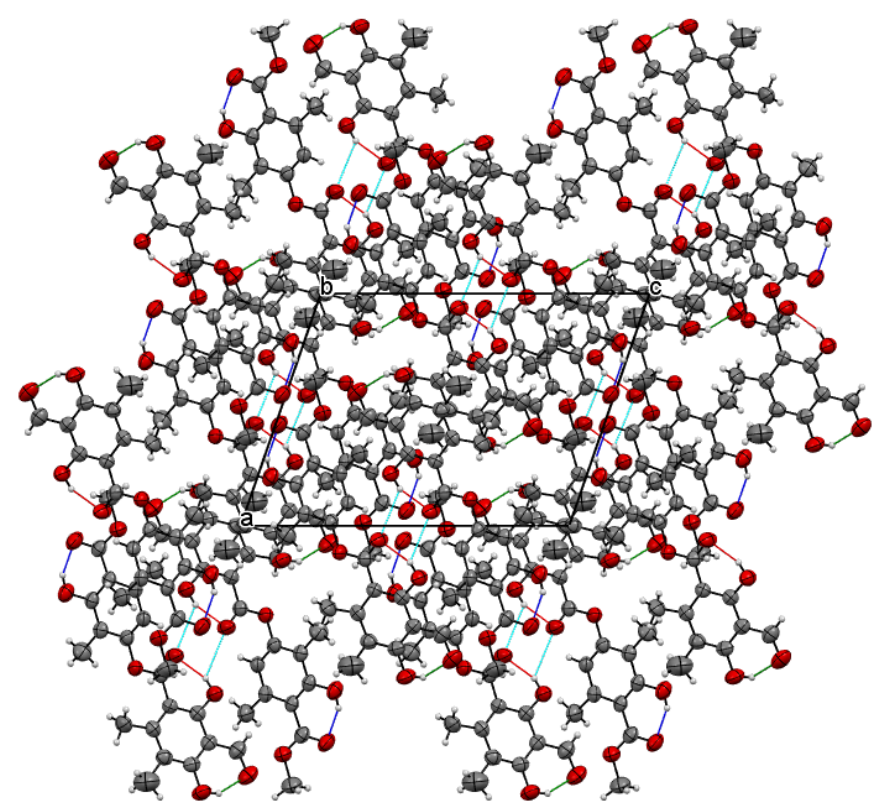

Figura 5. Stacking pattern in trüllarin.

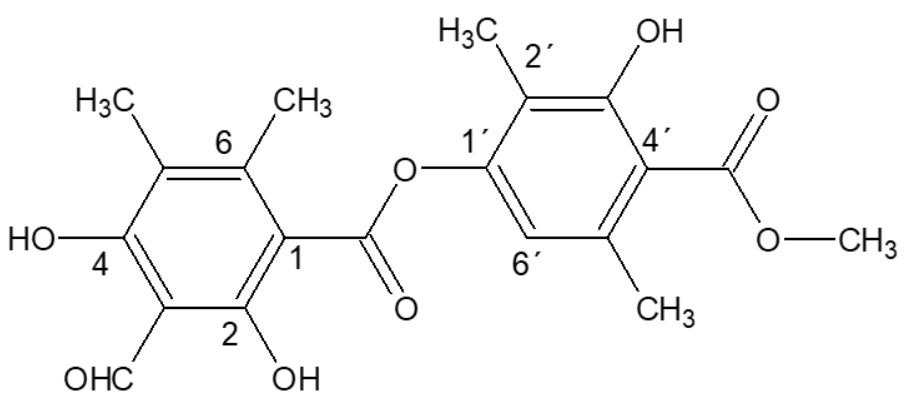

Figura 6. Chemical structure of trullarin.

\section{CONCLUSIONS}

Four compounds were isolated from the Peruvian Lichen E. trulla. One of them, compound $\mathrm{C}$ (trullarin), is reported for the first time. Has melting point of $198^{\circ} \mathrm{C}$ were obtained, whose structure was elucidated based on spectroscopic data (UV-Visible, IR, NMR-H ${ }^{1}$, NMR-C ${ }^{13}$, mass spectrometry and single crystal X-ray diffraction) and its chemical name is: (Methyl2,6-dimethyl-4 '- (3-formyl-2,4-dihydroxy-5,6-imethylbenzoyloxy) -3'-hydroxy benzoate). 


\section{BIBLIOGRAPHIC REFERENCES}

1. Dieu A, Millot M, Champavier, Mambu L, Chaleix V, Sol V, Gloaguen V. Uncommon chlorinated xanthone and other antibacterial compounds from the lichen cladonia incrassate. Planta Med. 2014; 80(11): 931-935.

2. Resende D, Pereira-Terra P, Inácio PS, Martins da Costa P, Pinto E, Sousa E, Pinto M. Lichen Xanthones as Models for New Antifungal Agents. Molecules, 2018; 23(10):2617. doi: 10.3390/molecules23102617.

3. Bruno M, Trucchi B, Burlando B, Ranzato E, Martinotti S, Küpeli Akkol E, et al. $(+)$-Usnic acid enamines with remarkable cicatrizing properties. Bioorg Med Chem. 2013; 21(7): 1834-1843.

4. Barrera Tomas M, Tomas Chota G, Sheen Cortavarría P, Fuentes Bonilla P, Inocente Camones MA, Santiago Contreras J. Synthesis of acyl-hydrazone from usnic acid and isoniazid and its anti-Mycobacterium tuberculosis activity. Rev Colomb Quím. 2017; (46):17-21.

5. Reynertson K, Wallace A, Adachi S, Gil R, Yang H, Basile M, et al. Bioactive Depsides and Anthocyanins from Jaboticaba (Myrciaria cauliflora). J Nat Prod. 2003; 69:12281230 .

6. Elix JA. Progress in the Generic Delimitation of Parmelia Sensu Lato Lichens (Ascomycotina: Parmeliaceae) and a Synoptic Key to the Parmeliaceae. The Biologist. 1993; 96(3): 359-383.

7. Ramaut JL, Brouers M, Serusiaux E, Corvisier M. Separation of mixtures of atranorin and chloroatranorin by thin-layer chromatography. [J Chromatogr. 1978; 155: 450-453.

8. Honda NK, Vilegas W. The chemistry of lichens. Quim Nova. 1999; 22:110-125.

9. Huneck S, Yoshimura I. Identification of lichen substances. Berlin: Springer; 1996.

10. Sheldrick GM. SHELXTL/PC User Manual. Madison, Wisconsin, USA.: Siemens Analytical X-ray Instruments Inc.; 1990.

11. Sheldrick GM. SHELXS97 and SHELXL97. Göttingen, Germany: University of Göttingen, Germany; 1997.

12. Macrae CF, Edgington PR, McCabe P, Pidcock E, Shields GP, Taylor R, et al. Mercury: visualization and analysis of crystal structures. J Appl Cryst. 2006; 39:453-457.

13. Cansaran D, Kahya D, Yurdakulol E, Atakol O. Identification and Quantitation of Usnic Acid from the Lichen Usnea Species of Anatolia and Antimicrobial Activity. Z Naturforsch. 2006; 61c: 773-776.

14. Carvalho M, Carvalho G, Braz-Filho R. Chemical Constituents from Ouratea floribunda: Complete $1 \mathrm{H}$ and 13C NMR Assignments of Atranorin and its New Acetyl Derivative. J Braz Chem Soc. 2000; 11(2):143-147.

15. Lv PC, Wang KR, Mao WJ, Fang RQ, Chen J, Xiong J, Zhu HL Synthesis and Crystal Structure of a Depside Derivative 2-(2-Methoxy-2-oxoethyl)phenyl 2-(3,4-Dimethoxyphenyl)acetate. J Chem. Crystallogr. 2009; 39:927-930.

16. Lv PC, Wang KR, Mao WJ, Fang RQ, Chen J, Xiong J, Zhu HL Synthesis, characterization and structure-activity relationship analysis of novel depsides as potential antibacterials. Eur J Med Chem. 2009; 44:1779-1787.

17. Wright JD. Molecular Crystals University of Kent at Canterbury. Cambridge, UK.: Cambridge University Press; 1995. 